\title{
Postsynaptic Targets of GABAergic Hippocampal Neurons in the Medial Septum-Diagonal Band of Broca Complex
}

\author{
Katalin Tóth, Zsolt Borhegyi, and Tamás F. Freund \\ Department of Functional Neuroanatomy, Institute of Experimental Medicine, Hungarian Academy of Sciences, Budapest, \\ $\mathrm{H}-1450$ Hungary
}

The termination pattern of hippocamposeptal nonpyramidal cells was investigated by injecting Phaseolus vulgaris leucoagglutinin (PHAL) into stratum oriens of the CA1 region. Electron microscopic analysis showed that the majority of the anterogradely labeled boutons formed symmetric synapses with dendrites and occasionally with cell bodies located in the medial septum-diagonal band of Broca complex. We have demonstrated with postembedding GABA immunocytochemistry that the majority of PHAL-labeled axon terminals were GABAergic. The neurochemical character of the postsynaptic target cells was also investigated using immunocytochemical double staining. Our data showed that the majority of the labeled hippocamposeptal axons innervated parvalbumin-immunoreactive cells representing GABAergic projection neurons, and a smaller number of contacts were found on ChAT-positive neurons. Septohippocampal neurons identified by retrograde HRP transport were also shown to receive direct hippocamposeptal input.

According to recent results, the lateral septum is unlikely to relay the hippocampal feedback to the medial septum; therefore, the direct hippocampal projection to the medial septum, arising from GABAergic nonpyramidal cells, seems to be the only feedback pathway to the area containing septohippocampal neurons. A novel circuit diagram, based on our recent morphological-immunocytochemical findings, is shown for the synaptic organization of the septo-hippocampo-septal loop. We suggest that the GABAergic hippocamposeptal feedback controls the activity of septal (mostly GABAergic) projection neurons as a function of hippocampal synchrony. The newly discovered reciprocal interactions may give a better insight into septohippocampal physiology.

IKey words: hippocampus, nonpyramidal cells, medial septum, ACh, Phaseolus vulgaris leucoagglutinin, anterograde tracing, parvalbumin, ChAT]

The septal projection to the hippocampus is considered crucial for the generation and maintenance of hippocampal theta activity and other behavior-related changes in the pattern of elec-

Received Oct. 13, 1992; revised Jan. 22, 1993; accepted Mar. 16, 1993.

We thank Drs. G. Buzsáki, J. Kiss, and 1. Soltész for helpful discussions, and Drs. K. G. Baimbridge, L. B. Hersh (funded by the Alzheimer's Disease and Related Disorders Assoc. Inc.), and P. Somogyi for gifts of antisera against PV, ChAT, and GABA. The excellent technical assistance of Ms E. Borok, Ms C. Pauletti, Ms I. Weisz, and Mr. G. Terstyánszky is also gratefully acknowledged. This study was supported by grants from OTKA (2920), Hungary; the Human Frontier Science Program; and the University of Kuopio, Finland.

Correspondence should be addressed to Tamás F. Freund, Ph.D., Institute of Experimental Medicine, Hungarian Academy of Sciences, Budapest, P.O. Box 67, H-1450, Hungary.

Copyright $(\mathcal{C} 1993$ Society for Neuroscience $0270-6474 / 93 / 133712-13 \$ 05.00 / 0$ trical activity (Petsche et al., 1962; Vanderwolf, 1969; Bland, 1986). The physiological properties, transmitters, and postsynaptic targets of the septohippocampal pathway are well established (Köhler et al., 1984; Wainer et al., 1984; Amaral and Kurz, 1985; Freund and Antal, 1988; Stewart and Fox, 1989; Gulyás et al., 1990) but much less is known about the hippocampal feedback to the medial septal area. Hippocampal pyramidal cells were shown to innervate the lateral septum (Jakab and Lcranth, 1990a,b; Leranth and Frotscher, 1989), which was thought to project to the medial septum, relaying the hippocampal feedback. However, recent tracing studies demonstrated that the lateral septal projection to the medial septum is sparse if it exists at all (Staiger and Nürnberger, 1991; Leranth et al., 1992). Thus, the direct innervation of the medial septal cells by hippocampal fibers appears to be the sole source of feedback to the medial septum. Alonso and Köhler (1982) demonstrated that, in contrast to the pyramidal cell projection to the lateral septum, the medial septum was innervated mostly, if not exclusively, by cells in stratum oriens of the CAl-CA3 regions, which appeared to be nonpyramidal according to their morphology and location. However, little is known about the postsynaptic targets and the transmitter of this direct feedback pathway. In an anterograde tracing study, Gaykema et al. (1991) showed that medial septal cholinergic cells were innervated by hippocamposeptal axons. On the basis of carlicr studics (Alonso and Köhler, 1982; Tóth and Freund, 1992), the GABAergic nature of this pathway may be predicted. Hippocampal neurons projecting to the medial septum were identified as nonpyramidal on the basis of their laminar distribution (Alonso and Köhler, 1982), dendritic arborization, and strong immunostaining for calbindin $\mathrm{D}_{28 \mathrm{~K}}$ (Tóth and Freund, 1992).

In the present study using anterograde Phaseolus vulgaris leucoagglutinin (PHAL) tracing in combination with postembedding GABA immunostaining, we demonstrate that the transmitter of the hippocampal projection to the medial septum is GABA. Furthermore, we investigated the neurochemical nature of the postsynaptic target cells of this pathway by immunocytochemical double staining for PHAL and parvalbumin (PV; a calcium-binding protein selectively present in GABAergic septal projection neurons), and PHAL and ChAT (the synthesizing enzyme of $\mathrm{ACh}$ ). The existence of monosynaptic input from hippocampal axons to septohippocampal neurons was also examined with a combination of anterograde PHAL and retrograde HRP tracing.

\section{Materials and Methods}

Animal surgery. Five adult male rats (Wistar, 300 gm; LATI, Gödöllö, Hungary) were used for the anterograde tracing study, and 10 additional rats for the combined anterograde and retrograde tracing experiments. 
Hippocamposeptal axons were visualized by anterograde transport of Phaseolus vulgaris leucoagglutinin (PHAL; $2.5 \%$; Vector Laboratories). The tracer was iontophoresed, using the protocol of Gerfen and Sawchenko (1984), into the dorsal hippocampus under deep Equithesin anesthesia (chlornembutal, $0.3 \mathrm{ml} / 100 \mathrm{gm}$ ) at the following coordinates aiming at stratum oriens of the CA1 region: $3.2 \mathrm{~mm}$ and $4 \mathrm{~mm}$ posterior to the bregma; $1 \mathrm{~mm}, 2 \mathrm{~mm}$, and $3 \mathrm{~mm}$ lateral to the midline; and 2.3 $\mathrm{mm}$ or $2.6 \mathrm{~mm}$ below the pial surface (six sites). Retrograde transport of horseradish peroxidase (HRP; $20 \%$ in saline) was used to visualize septohippocampal neurons. The ventral hippocampus was injected at four sites in the same hemisphere as with PHAL at the following coordinates: $4.2 \mathrm{~mm}$ and $4.6 \mathrm{~mm}$ posterior to the bregma, $4.6 \mathrm{~mm}$ lateral to the midline, and $7 \mathrm{~mm}$ and $7.4 \mathrm{~mm}$ below the pial surface. A volume of 250-300 $\mathrm{nl}$ of the HRP solution was injected at each site in each animal by pressure through a glass capillary, which was left in place for 15 min to prevent the spread of the tracer back along the capillary track.

Seven days after the PHAL, and $3 \mathrm{~d}$ after the HRP injection, the animals were anesthetized again with Fquithesin and perfused first with physiological saline $(1 \mathrm{~min})$ and then with a fixative containing (1) $1 \%$ glutaraldehyde, $2 \%$ paraformaldehyde, and $0.2 \%$ picric acid in $0.1 \mathrm{M}$ phosphate buffer (PB) for the anterograde tracing study, or (2) $0.1 \%$ glutaraldehyde, $4 \%$ paraformaldehyde, and $0.2 \%$ picric acid in $0.1 \mathrm{M}$ $\mathrm{PB}$ for the combined anterograde-retrograde tracing and choline acetyltransferase (ChAT) or parvalbumin (PV) immunocytochemical study, for $30 \mathrm{~min}$. The brains were removed, and the septal region and the hippocampus were dissected and postfixed in the same fixative for 30 min to $2 \mathrm{hr}$.

Horseradish peroxidase histochemistry and double immunocytochemistry. Vibratome sections ( $60 \mu \mathrm{m}$ thick) were cut from the septal region and the injection sites, and the sections were washed in $0.1 \mathrm{M} \mathrm{PB}(\mathrm{pH}$ 7.4) for $5 \times 30 \mathrm{~min}$. The sections for electron microscopy were immersed in $10 \%$ and $30 \%$ sucrose, freeze-thawed in liquid nitrogen, extensively washed in $0.1 \mathrm{M} \mathrm{PB}$, and processed for immunocytochemistry.

In sections of the HRP tracing experiment, the transported HRP was visualized using nickel-intensified 3,3'-diaminobenzidine (DAB; Sigma) as a chromogen (Hancock, 1982). These sections were processed further to visualize PV or ChAT and PHAL by immunocytochemistry.

For double immunocytochemistry the sections were treated with the following solutions: $10 \%$ normal goat serum (NGS) for $1 \mathrm{hr}$, a mixture of biotinylated anti-PHAL (Vector Labs, Burlingame, CA; 1:200) and polyclonal antiparvalbumin (Baimbridge and Miller, 1982) (1:1000) or polyclonal anti-ChAT (Bruce et al., 1985) (1:200) for $2 \mathrm{~d}$, or anti-PHAL alone for the anterograde study. This was followed by incubation in a mixture of avidin-biotinylated horseradish peroxidase complex $(1: 100$ Elite ABC, Vector Labs) and goat anti-rabbit IgG (1:50; ICN, Costa Mesa, CA) for $6 \mathrm{hr}$. The first immunoperoxidase reaction (for PHAL) was developed using $\mathrm{DAB}$ as a substrate intensified with ammonium nickel sulfate (black reaction product; Hancock, 1982). The third layer $(12 \mathrm{hr})$ was rabbit peroxidase-antiperoxidase complex (1:100; Dakopatts, Glostrup, Denmark). The second immunoreaction was developed with DAB alone (brown reaction product). All the washing and dilution of antisera were in $50 \mathrm{~mm}$ Tris-buffered saline (TBS) containing $1 \%$ NGS and $0.5 \%$ Triton $X-100$. Triton $X-100$ was omitted when sections were processed for electron microscopy. When only PHAL was visualized, $\mathrm{DAB}$ was used instead of $\mathrm{DAB}-\mathrm{Ni}^{2}+$ to avoid possible nonspecific colloidal gold labeling during the postembedding GABA immunostaining. The sections for light microscopy were mounted on gelatin-coated slides, dried, immersed in xylene, and embedded in XAM (BDH, Poole, England) neutral medium. Other sections were processed according to the electron microscopic protocol. Following osmium tetroxide treatment $\left(1 \% \mathrm{OsO}_{4}\right.$ in $0.1 \mathrm{M} \mathrm{PB}$ for $\left.45 \mathrm{~min}\right)$ the sections were dehydrated in ascending ethanol series ( $1 \%$ uranyl acetate was included in the $70 \%$ ethanol step for $40 \mathrm{~min}$ ) and propylene oxide, and embedded in Durcupan (ACM, Fluka).

Postembedding immunogold staining for GABA. From the material of the anterograde study, alternate ultrathin sections were mounted on copper and nickel grids and postembedding GABA immunostaining was carried out on the nickel grids. The steps were made on droplets of solutions in humid Petri dishes as described earlier (Somogyi and Hodgson, 1985), briefly, $1 \%$ periodic acid $\left(\mathrm{H}_{5} \mathrm{IO}_{6}\right)$ for $10 \mathrm{~min}$; wash in distilled water; $2 \%$ sodium metaperiodate $\left(\mathrm{NaIO}_{4}\right)$ for $10 \mathrm{~min}$; wash in distilled water; $3 \times 10 \mathrm{~min}$ in TBS containing $1 \% \mathrm{NGS} ; 1.5 \mathrm{hr}$ in rabbit anti-GABA antiserum (Hodgson et al., 1985) diluted 1:3000 in NGS/ TBS; $2 \times 10 \mathrm{~min}$ in TBS; $10 \mathrm{~min}$ in TBS containing $1 \%$ bovine serum albumin, $0.05 \%$ Tween 20 , and $1 \%$ NGS; 2 hr in goat anti-rabbit IgG- coated colloidal gold (15 nm, Amersham 1:10) diluted in the same solution as before; $2 \times 5 \mathrm{~min}$ wash in distilled water; $30 \mathrm{~min}$ in saturated uranyl acetate; wash in distilled water; staining with lead citrate; wash in distilled water.

Controls. The specificity of the antiserum, including adsorption controls, has been described by Hodgson et al. (1985). In the present experiments the controls included replacement of the primary antiserum with normal rabbit serum $(1: 1000)$ and the same protocol was carried out. No accumulation of gold particles was observed over any profiles (either PHAL labeled or not), only a homogeneous background was visible on these control sections.

\section{Results}

\section{Location of PHAL and HRP injection sites}

PHAL was injected in each animal at six sites in one hemisphere. Examination of the injection sites revealed a strong labeling within the CA1 region of the hippocampus, centered in strata pyramidale and oriens, and in two rats the CA3 region and the dentate gyrus were injected as well. Both pyramidal and nonpyramidal cells were labeled (Fig. 1). The HRP injections were made into the ventral hippocampus to avoid extensive overlaps with the PHAL injection site. The center of the injection was in the CA3 region and in the dentate gyrus, whereas in five rats the CA1 region was labeled as well. No spread of either tracers outside the hippocampal formation was observed in any of the 15 rats.

For technical reasons the dorsal hippocampus was selected for PHAL injections, but similar results can be obtained following ventral hippocampal placements of the tracer. Details of the topography of this projection have been described previously (Gaykema et al., 1991).

\section{Distribution of PHAL-labeled hippocampal axons in the medial septum-diagonal band complex}

PHAL-labeled axons were found in the lateral septum and in the medial septum-diagonal band of Broca (ms-dbB) complex. The distribution of the labeled hippocamposeptal fibers (Fig. 1) was similar to that described earlier (Swanson and Cowan, 1977; Gaykema et al., 1991). A network of thin fibers possessing several small varicosities was observed in the lateral septal area. These axons are known to originate from hippocampal pyramidal cells (Leranth and Frotscher, 1989; Jakab and Leranth, 1990a,b). PHAL-labeled axons in the ms-dbB complex were considerably thicker and formed large en passant varicosities. On the basis of earlier studies (Alonso and Köhler, 1982; Tóth and Freund, 1992), axons terminating in this region are likely to originate from hippocampal nonpyramidal cells. Thick main axons ran mostly vertically through the medial septum, and frequently emitted thinner, bouton-laden collaterals that either turned laterally and ended within a hundred micrometers, or turned vertically and ran parallel with the main axons. Occasionally, side branches were seen to form basketlike arrays of large boutons around unstained cell bodies. At the border of the horizontal and vertical limbs of the diagonal band, an ovalshaped dense network of PHAL-labeled fibers was consistently observed, with several large boutons intermingled with densely packed cell bodies.

\section{GABA immunoreactivity and postsynaptic targets of hippocampal afferents in the medial septum}

Tissue blocks of the ms-dbB complex containing PHAL-labeled boutons were reembedded and a total of 55 boutons were serially sectioned and reconstructed in the electron microscope. Alter- 

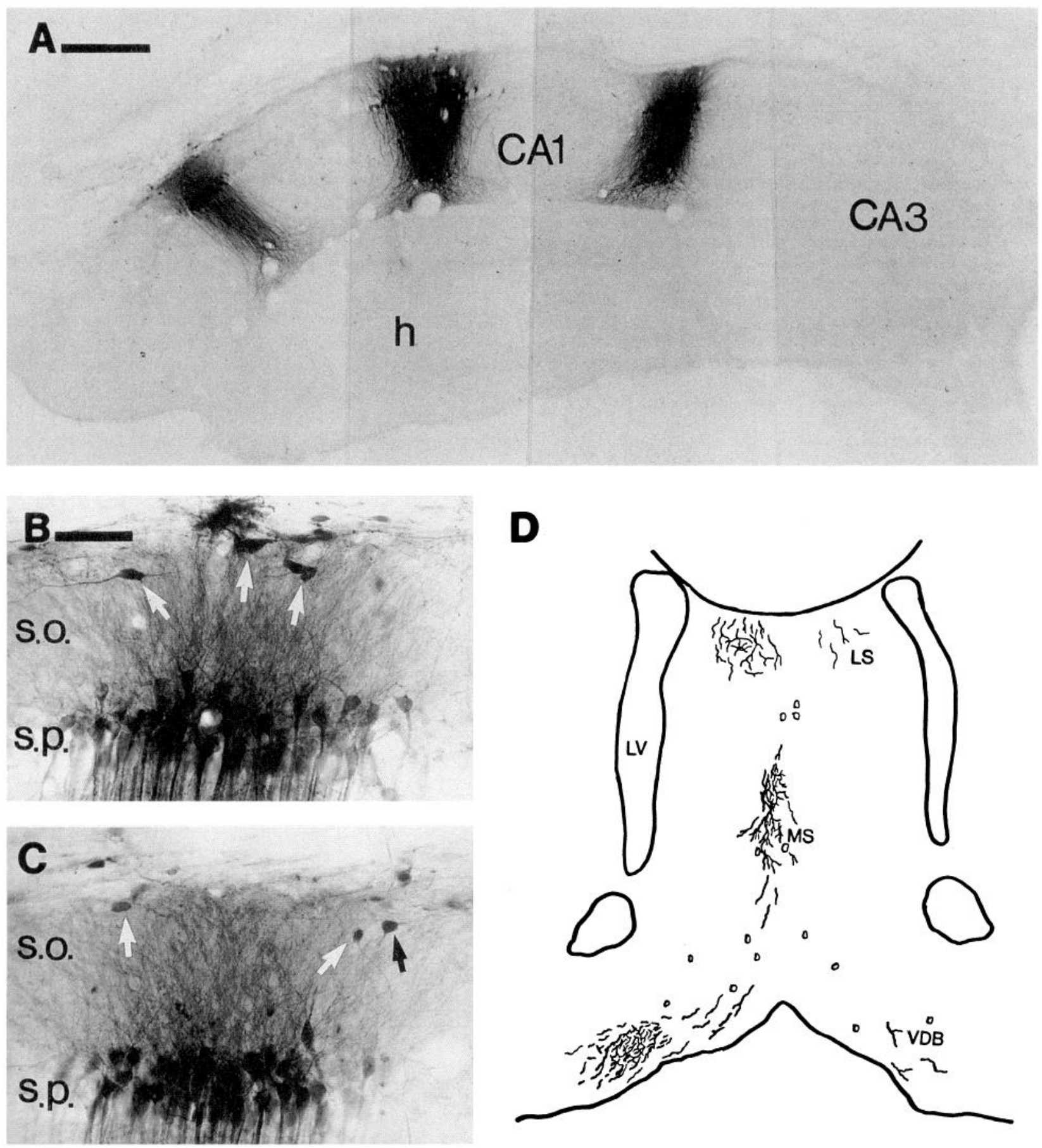

Figure 1. A, Low-power light micrograph of three PHAL injection sites in the CAl region of the hippocampus centered in strata pyramidale and oriens, which labeled the entire dendritic tree of pyramidal cells extending down to the hippocampal fissure. $B$ and $C$, At higher magnification PHAL-filled pyramidal as well as nonpyramidal cells (arrows) in stratum oriens are visible. $D$, Distribution of PHAL-labeled axons in the septal region is illustrated by a camera lucida drawing ( 2 adjacent sections superimposed). $h$, hilus; s.o., stratum oriens; s.p., stratum pyramidale; $L V$, lateral ventricle; $L S$, lateral septum; $M S$, medial septum; $D B$, diagonal band of Broca. Scale bars: $A, 400 \mu \mathrm{m} ; B$ and $C, 100 \mu \mathrm{m}$.

nate grids were immunostained for GABA using the immunogold procedure. All examined axon terminals were found to establish symmetrical synaptic contacts with their postsynaptic targets (Fig. 2). The majority of these targets (93\%) were dendritic shafts (Fig. 2A,B), and occasionally cell bodies (Figs. 3, 4) and spines. Most of the postsynaptic dendrites were varicose and could receive hippocampal synapses onto their large-diameter as well as intervaricose segments. They contained large mitochondria and received other symmetric and asymmetric synapses. The intervaricose segments were difficult to distinguish from dendritic spines in cross sections, although the accumulation of regularly spaced microtubules, which were occasionally visible, suggested that they were dendritic shafts (intervaricose segments) rather than spines. None of the target profiles contained a spine apparatus.

On alternate grids the GABA immunoreactivity of the PHAL- 

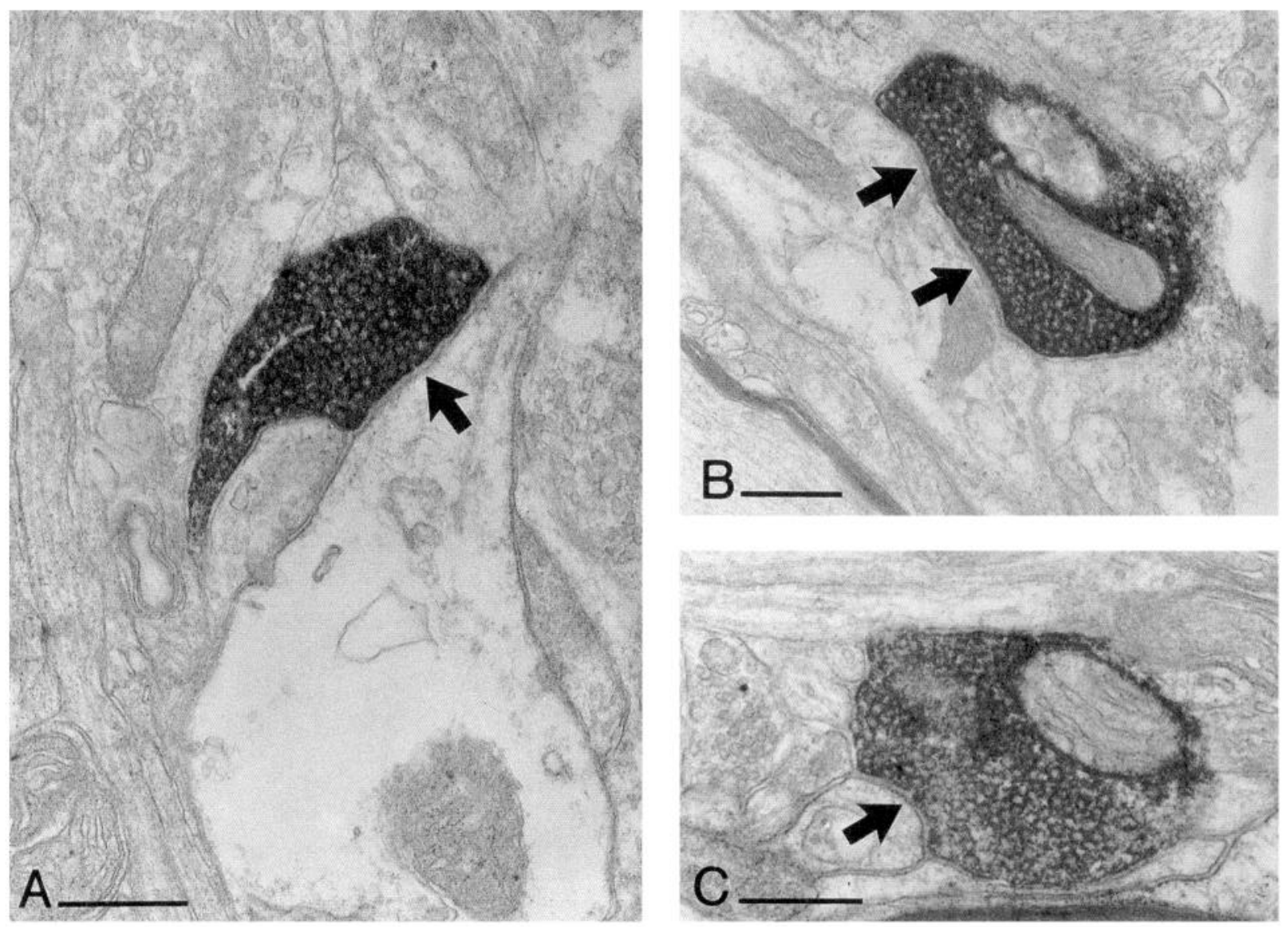

Figure 2. PHAL-labeled hippocampal boutons in the medial septum form symmetric synaptic contacts (arrows) with various postsynaptic targets, that is, with a varicose dendrite $(A)$, with a smooth dendrite $(B)$, and with a small spine-like profile or intervaricose segment $(C)$. Scale bars, $0.4 \mu \mathrm{m}$.

labeled boutons and of their postsynaptic targets has been examined. The profiles that definitely lack GABA in this region are the axon terminals making asymmetric synapses, and therefore these profiles served as controls to determine the background level. Any boutons (whether PHAL labeled or not) were considered GABA positive if they showed a gold particle density at least five times that of the asymmetric synaptic boutons (asymmetric synaptic boutons are indicated on each electron micrograph to facilitate comparison). For the majority of PHALlabeled boutons a precise quantification was unnecessary, since the difference from background was usually more than 10 times, but in questionable cases we have used the above method. In addition, serial sections of the same PHAL-labeled boutons were examined to confirm that their GABA positivity is consistent from section to section. The majority (94\%) of the PHAL-labeled hippocampal boutons were immunoreactive for GABA (Figs. 4,5$)$. The remaining terminals $(6 \%)$ were probably false negative, since they did not contain mitochondria. In PHALlabeled boutons most of the colloidal gold labeling is found over mitochondria, since the preembedding immunoperoxidase reaction product does not penetrate into these organelles, and therefore GABA immunoreactivity is not masked. Postsynaptic targets of the PHAL-labeled hippocamposeptal boutons were either negative for GABA or labeled at background level. The equivocal staining of ms-dbB neurons for GABA was expected, since without the use of colchicine the somatic level of GABA in the GABAergic neurons with distant projections is below the sensitivity threshold of immunocytochemistry (Onteniente et al., 1986). This specific but weak and unpredictable labeling of GABAergic somata and dendrites is the reason why labeling of these profiles was never used as an indication of background level (see Discussion). To characterize further and identify the postsynaptic targets of hippocamposeptal afferents, we combined anterograde PHAL tracing with immunostaining for PV or ChAT, and retrograde HRP transport.

\section{Distribution of PV-and ChAT-immunoreactive cells and retrogradely labeled septohippocampal neurons}

The distribution of the retrogradely HRP-labeled cells was unilateral, the vast majority of them being found in the injected hemisphere. HRP-labeled cells were present in the medial septum and in the vertical and horizontal limbs of the diagonal band, with highest numbers in the medial septum (Fig. 6A).

The distribution of PV-and ChAT-immunoreactive cells was similar to that described earlier (Baimbridge et al., 1982; Sofroniew et al., 1982; Cuello and Sofroniew, 1984; Wainer et al., 1984; Amaral and Kurz, 1985; Heizmann and Celio, 1987; Kiss et al., 1990a,b). ChAT-positive neurons were found in large numbers throughout the medial septum mainly lateral to the midline. In the diagonal band of Broca they formed an ovalshaped circle with a center zone poor in immunoreactive cells and processes (Fig. $7 A, B$ ). The center of this circle was occupied by densely packed cell bodies and processes of PV-positive neurons (Kiss et al., 1990b), as shown with double immunostaining in Figure $7 B$. The morphological appearance of the ChAT- and PV-immunoreactive cells was similar. PV-containing cells were 


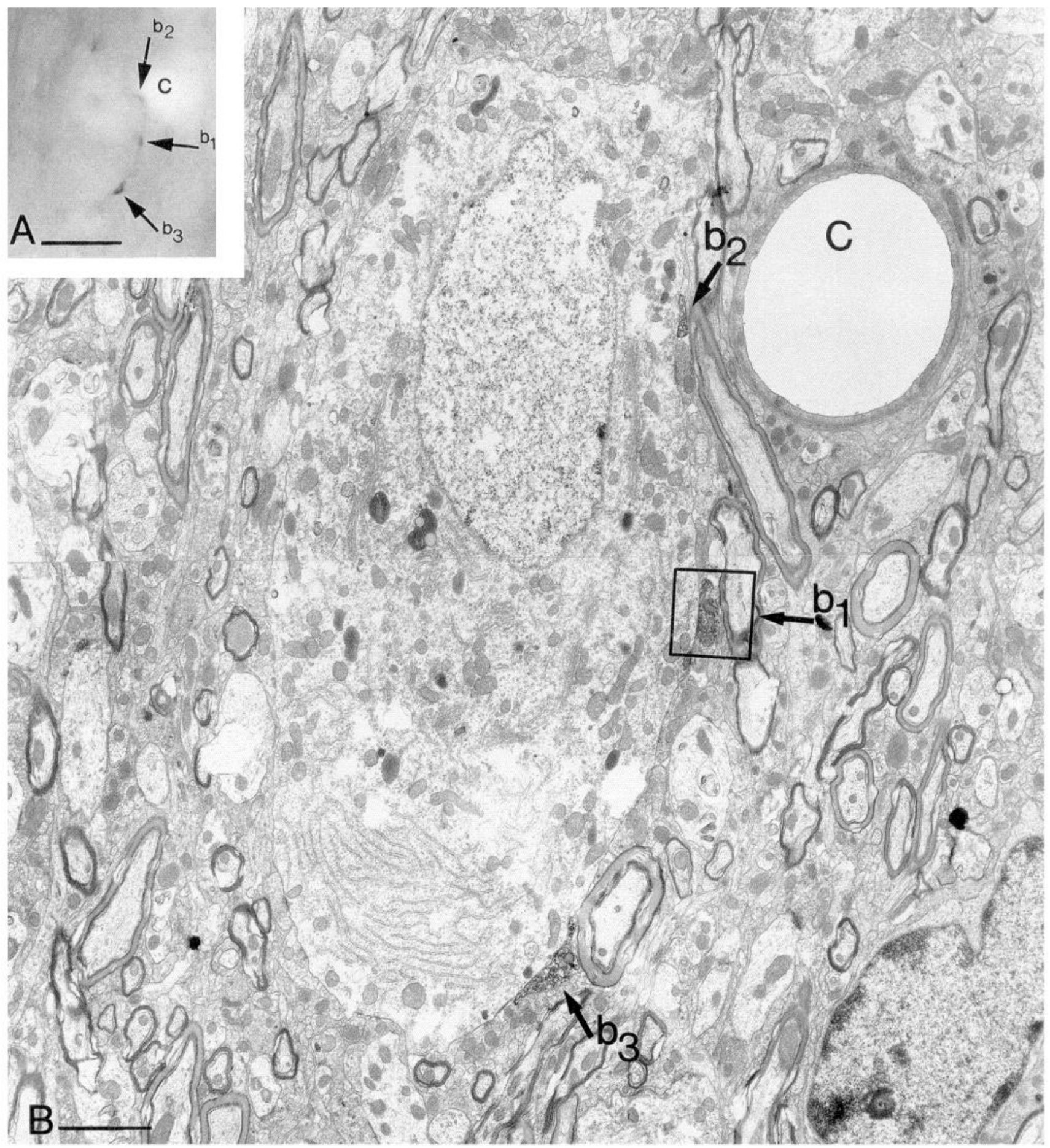

Figure 3. A, Light micrograph of boutons $\left(b_{1}-b_{3}\right)$ of a PHAL-labeled hippocamposeptal axon surrounding a cell body in the medial septum. $B$, Low-power electron micrograph of the cell body shown at the light microscopic level in $A$, receiving synaptic contacts from three PHAL-labeled boutons $\left(b_{1}-b_{3}\right.$, arrows). The synapse formed by bouton $b_{1}$ is shown at higher magnification in Figure 4 . A capillary (c) serves as a landmark for the identification of the cell on the light and electron micrographs. Scale bars: $A, 10 \mu \mathrm{m} ; B, 2 \mu \mathrm{m}$.

observed close to the midline of the medial septum, medial from the groups of cholinergic neurons, and present in all parts of the diagonal band, forming a cell group surrounded by ChATpositive neurons. PV-immunoreactive cells in the medial septum were mainly medium-sized with elongated shape, oriented in parallel with the dorsoventral axis. The PV-positive neurons in the diagonal band were relatively large and had a multipolar or oval shape oriented parallel with the main fiber bundles.
Innervation of $P V$ - and ChAT-immunoreactive cells and retrogradely labeled septohippocampal neurons by hippocamposeptal fibers

The examination of septal sections double stained for PHAL and PV or ChAT revealed that both PV- and ChAT-immunoreactive cells were among the targets of the hippocamposeptal neurons in the ms-dbB complex but with a remarkably different 

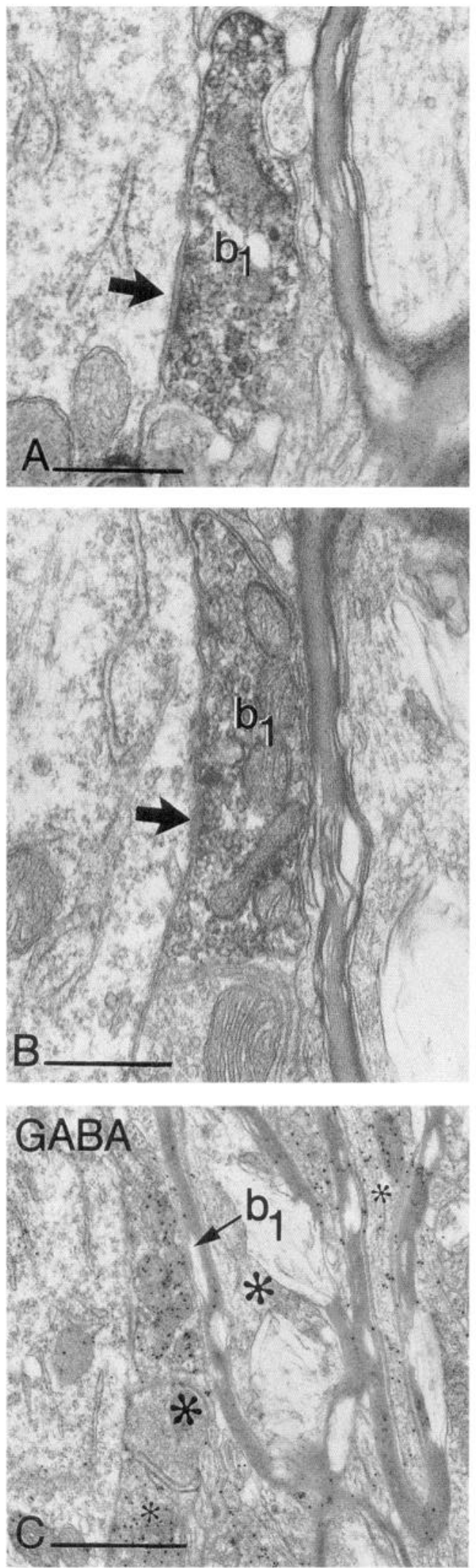
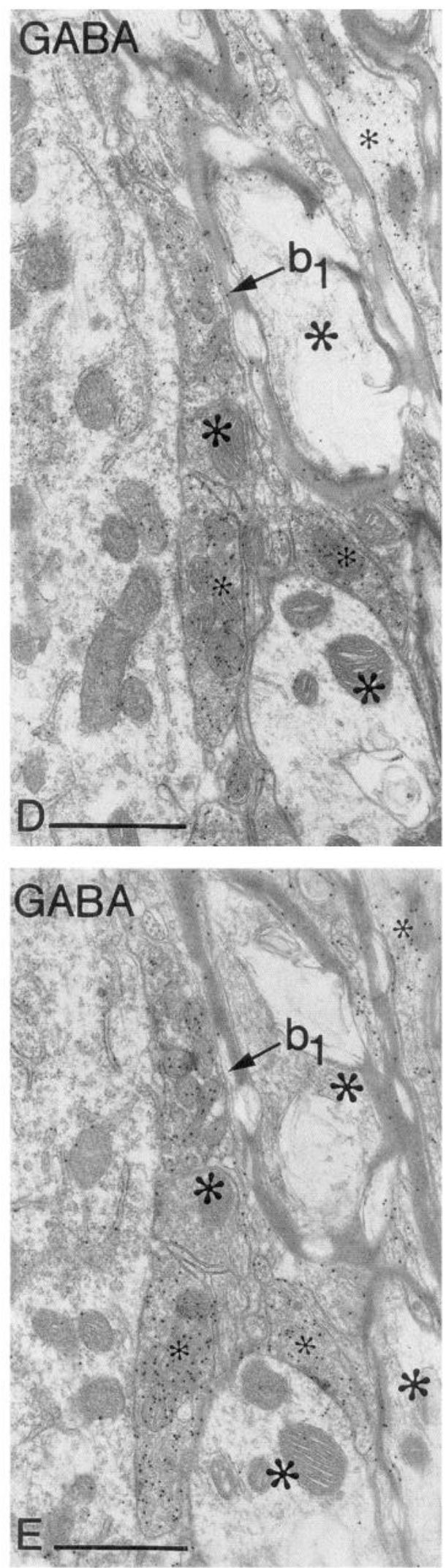

Figure 4. A, Bouton $b_{l}$ (framed in Fig. $3 B$ ) is shown here at high power to form a symmetric synaptic contact (arrow) with the soma of the cell. $B$, Another section of the same PHAL-labeled bouton is shown to facilitate correlation with other three sections of the same bouton farther away in the series of sections, which were stained for GABA using the immunogold procedure. $C-E$, Neighboring ultrathin sections immunostained for GABA demonstrate that the PHAL-labeled bouton $\left(b_{l}\right)$ is immunoreactive for GABA, as indicated by the accumulation of colloidal gold particles. Other GABA-positive profiles (small asterisks) and GABA-negative axon terminals, myelinated axons, and dendrites (large asterisks) are also indicated. The postsynaptic cell body also shows some degree of colloidal gold labeling. Note that the PHAL-labeled boutons lose their electron density during the postembedding immunostaining procedure. Scale bars: $A$ and $B, 0.5$ $\mu \mathrm{m} ; C-E, 1 \mu \mathrm{m}$. frequency. Hippocamposeptal axons formed multiple contacts with cell bodies and dendrites of mostly PV-positive (Fig. $7 \mathrm{C}$ $H$ ) but occasionally also with ChAT-positive neurons (Fig. 7I,J). Single contacts were frequently found on ChAT-positive cells as well. Only the number of PV- or ChAT-positive cells receiving multiple contacts was quantified, since single light microscopically identified contacts often turn out to lack a synaptic specialization between the labeled profiles, the labeled bouton 

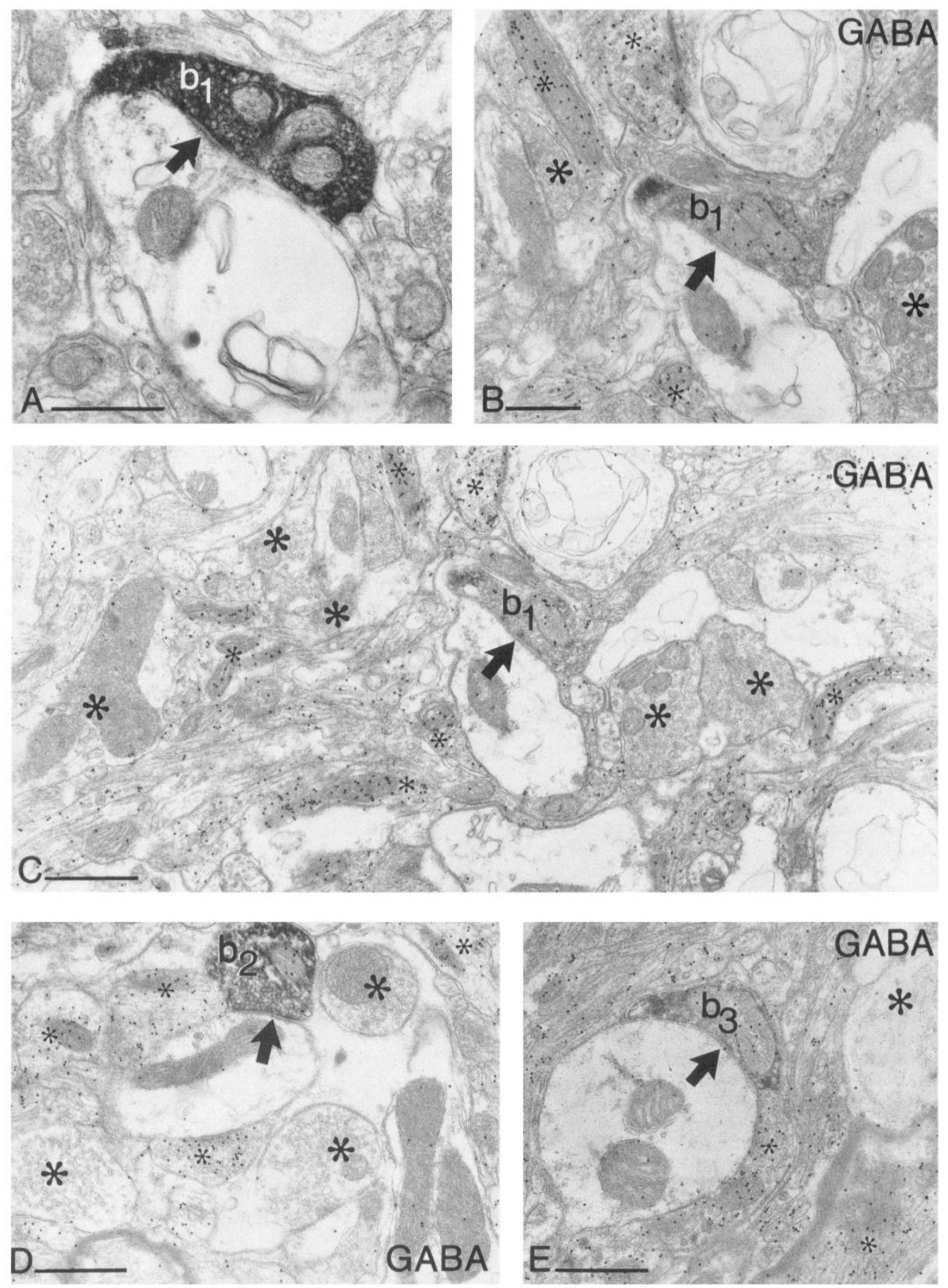

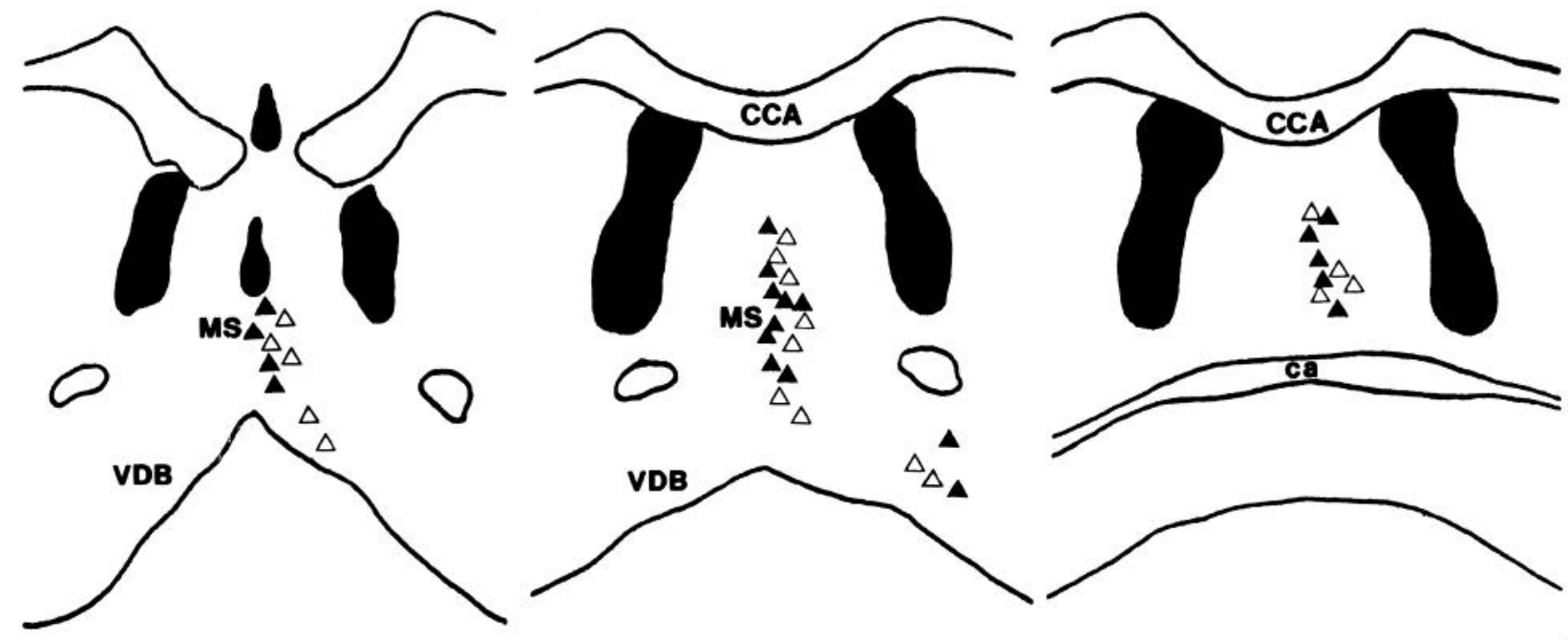

A
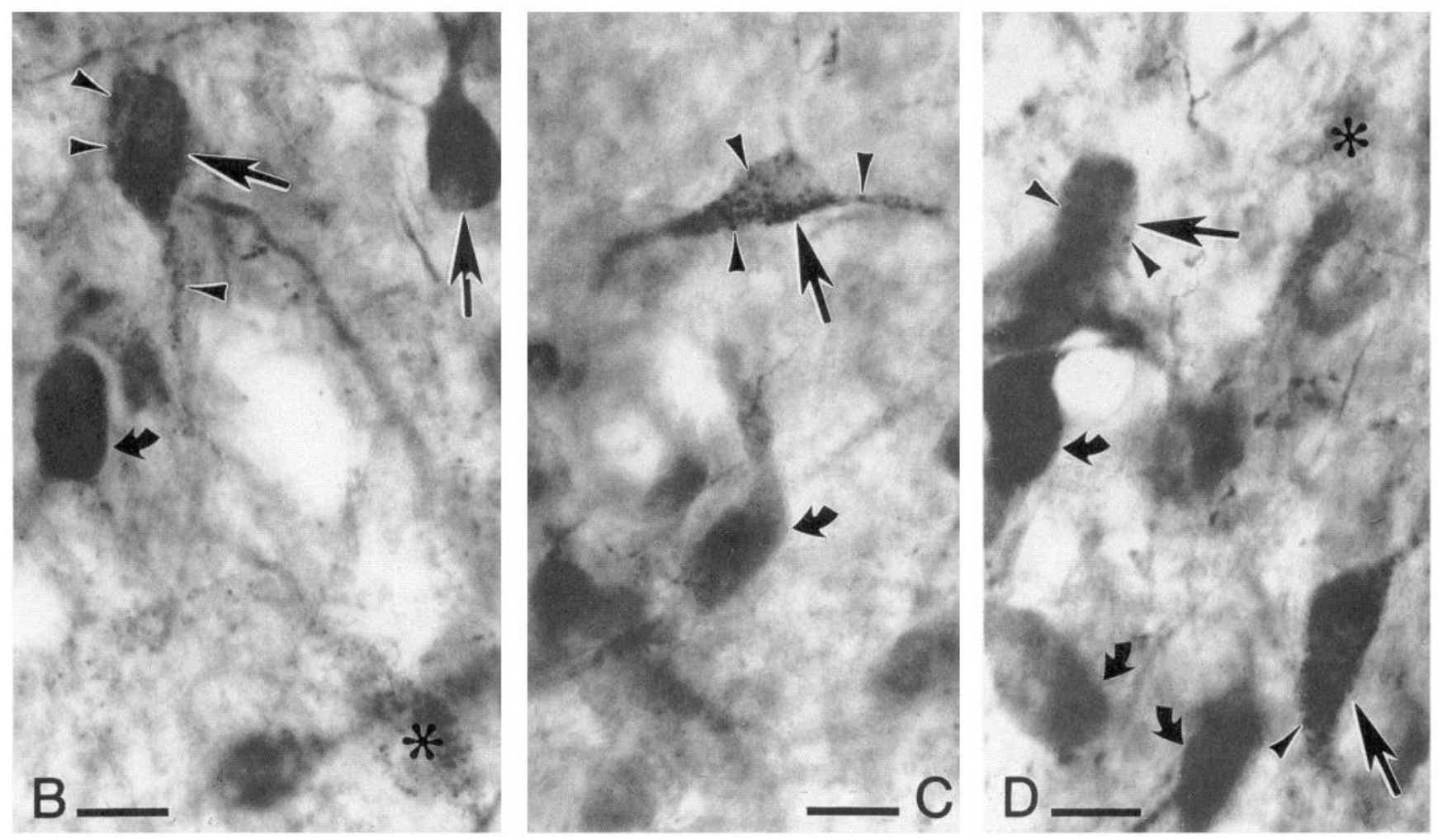

Figure 6. A, Distribution of retrogradely labeled neurons in the septum following HRP injections into the ventral hippocampus. Open triangles indicate PV negative, and solid triangles, PV-immunoreactive retrogradely labeled cells. Note that approximately half of the projecting neurons are immunoreactive for PV and the projection is almost exclusively unilateral. $B-D$, Light micrographs of sections double stained for PV and retrogradely transported HRP. Double-labeled cells (large arrows) can be clearly identified even in black and white; the end product of retrogradely transported HRP (arrowheads) is granular (black, DAB-Ni ${ }^{2+}$ ), whereas that of the immunoperoxidase is homogeneous (brown, DAB). Curved arrows indicate PV-positive cells not labeled by retrograde HRP, whereas asterisks indicate PV-negative retrogradely labeled neurons. ca, anterior commissure; $C C A$, corpus callosum; $M S$, medical septum; $V D B$, vertical limb of the diagonal band of Broca. Scale bars, $10 \mu \mathrm{m}$.

Figure 5. A, A dendritic shaft in the medial septum is receiving a symmetrical synaptic contact (arrow) from a PHAL-labeled hippocamposeptal bouton $\left(b_{t}\right) . B$ and $C$, The PHAL-labeled bouton $\left(b_{1}\right.$, shown in $A$ ) is immunoreactive for GABA as indicated by the accumulation of colloidal gold particles on these immunostained sections, adjacent to that seen in $A$. $D$ and $E$, Two other PHAL-labeled hippocampal boutons $\left(b_{2}, b_{3}\right)$ form symmetric synaptic contacts in the medial septum with dendritic profiles. Both boutons are immunoreactive for GABA. Other GABA-positive (small asterisks) and GABA-negative (large asterisks) profiles are labeled to indicate the level of background staining. The postsynaptic dendrites of each of the three boutons are negative for GABA. Scale bars: $A$ and $B, 0.5 \mu \mathrm{m} ; C-E, 0.75 \mu \mathrm{m}$. 

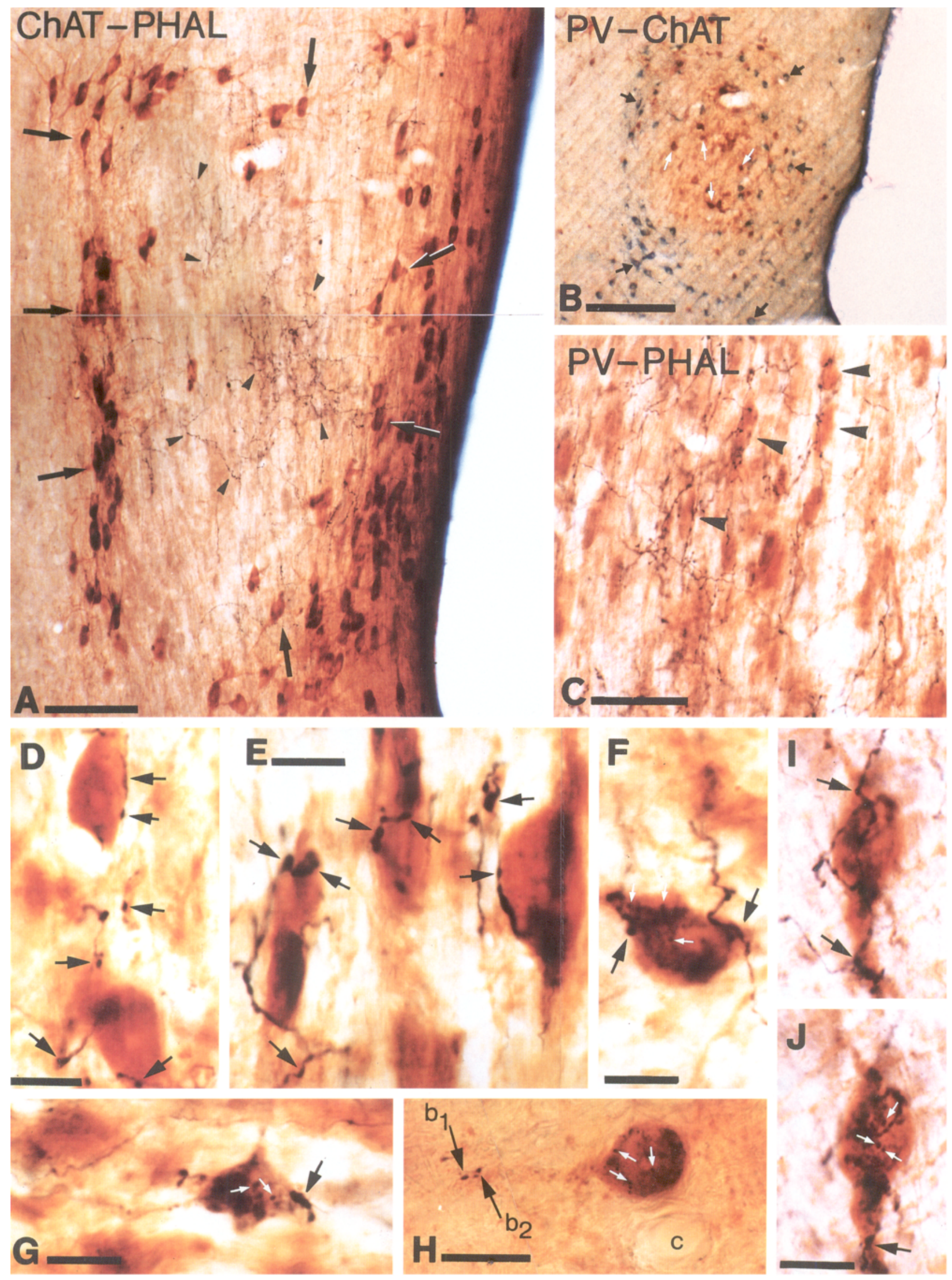
synapsing onto another unstained profile. In contrast, multiple contacts between labeled profiles always proved to be synaptic in the electron microscope (see, e.g., Gulyás et al., 1990). Cell counts were made from four sections of two animals for both ChAT and PV, at similar rostrocaudal levels. In the medial septum 39 PV-containing cells and 9 ChAT-immunopositive neurons, compared to $42 \mathrm{PV}$-positive and $8 \mathrm{ChAT}$-positive neurons in the diagonal band, were innervated by the PHAL-labeled hippocamposeptal fibers in a basket-like fashion. These quantitative data supported our qualitative observations; that is, in the center of the oval-shaped ring formed by ChAT-positive neurons in the vertical limb of the diagonal band, the dense arborization of the hippocamposeptal fibers coincided with a high packing density of PV-positive cells (Fig. $7 A, B$ ). Similarly, in the medial septum, the area medial to the cholinergic cell groups was rich in PHAL-labeled fibers, coinciding with the distribution of PV-positive cells.

Injections of HRP into the ventral hippocampus resulted in the retrograde labeling of several neurons in the ms-dbB complex ipsilateral to the injections (Fig. 6A). The same septal sections were also immunostained for PV or ChAT, and the retrogradely labeled cells were identified in this way as cholinergic or GABAergic. The granular reaction end product of the retrogradely transported HRP (black) was clearly distinguishable from the homogeneous brown immunoperoxidase staining (Fig. $6 B-D)$. Examination of the retrogradely labeled cells showed that some of them received multiple contacts from PHAL-labeled hippocamposeptal fibers, providing evidence for a direct hippocampal input to septohippocampal neurons (Fig. $7 F-J$ ). Both PV- and ChAT-immunoreactive retrogradely labeled neurons were among the targets of the hippocamposeptal fibers, but the former were far more numerous.

\section{Discussion}

In the present study we demonstrated that (1) the majority of PHAL-labeled hippocampal fibers in the ms-dbB complex are GABAergic and form symmetrical synaptic contacts mostly with dendritic profiles and cell bodies, (2) the majority of the anterogradely labeled hippocamposeptal axons innervated PV-containing cells but a smaller number of contacts were found also on ChAT-immunoreactive neurons in the ms-dbB complex, and (3) the PHAL-labeled axons formed multiple contacts also with retrogradely HRP-labeled cells, providing evidence for a direct hippocamposeptal input to septohippocampal neurons.

\section{Distribution of hippocamposeptal axons}

It has been shown in earlier studies that hippocampal neurons are projecting to the lateral as well as to the medial septal area (Raisman, 1966; Swanson and Cowan, 1979; Alonso and Köhler, 1982; Leranth and Frotscher, 1989; Gaykema et al., 1991). Our findings support and extend these data concerning the origin, morphological features, and transmitter content of these projections. Hippocampal axons terminating in the lateral septum are known to originate from pyramidal cells (Swanson and Cowan, 1979; Leranth and Frotscher, 1989; Jakab and Leranth, $1990 \mathrm{~b})$. The morphological features of the labeled axons in the lateral septum were different from fibers arborizing in the ms$\mathrm{dbB}$ complex. The former were thin and studded with small boutons that form asymmetric synapses (Jakab and Lcranth, $1990 \mathrm{~b}$ ), whereas the latter were thick with large varicosities, forming symmetrical synapses (present results). Neurons in stratum oriens of the hippocampus with morphological features and location characteristic of nonpyramidal cells were found to be responsible for the projection to the medial septum (Alonso and Köhler, 1982), and the majority of these neurons were later shown to belong to the calbindin-containing subpopulation in stratum oriens (Tóth and Freund, 1992).

\section{PHAL-labeled hippocampal axons in the $m s-d b B$ complex are immunoreactive for $G A B A$}

In the present study we provided direct evidence that almost all $(94 \%)$ of the hippocampal axons terminating in the ms-dbB complex were GABAergic and only a small proportion $(6 \%)$ of the labeled boutons were found to be GABA negative. However, none of the $\mathrm{G} \Lambda \mathrm{B} \Lambda$-negative terminals containcd mitochondria in the immunostained sections, and the strongest immunogoldstaining for GABA is known to occur over mitochondria (Somogyi and Hodgson, 1985; Somogyi and Soltesz, 1986). These GABA-negative terminals also formed symmetric synaptic contacts, unlike those in the lateral septum, suggesting that their staining may be false negative. A preferential transport of PHAL by GABAergic neurons has been suggested for septohippocampal neurons in the rat (Freund and Antal, 1988; Freund, 1989) and monkey (Gulyás et al., 1991) and for GABAergic basket cells in the cat neocortex (A. I. Gulyás, T. P. Freund, and Z. F. Kisvárday, unpublished observations). We cannot exclude the possibility that this kind of preferential labeling occurred in this study as well, although the strong labeling of pyramidal cell

\footnotetext{
Figure 7. A, Double immunostaining for ChAT (brown, DAB) and PHAL (black, DAB-Ni ${ }^{2+}$ ) in the vertical limb of the diagonal band of Broca. ChAT-positive neurons (arrows) form a characteristic oval circle. The majority of the PHAL-labeled hippocampal axons (arrowheads) are arborizing within this circle, where the density of ChAT-positive cells and processes is very low. $B$, The same region of the vertical limb as in $A$ is shown here immunostained for PV (in brown, white arrows) and ChAT (in blue, black arrows). This photograph was taken from an earlier material and the procedure is described there (Kiss et al., 1990b). Note that the PV-immunopositive cells occupy the middle of the circle formed by the ChATpositive cells, coinciding with the distribution of PHAL-labeled hippocamposeptal axons (shown in $A$ ). $C$, The same area, the center of the circle, is shown at higher magnification, immunostained for PV (in brown) and PHAL (in black). Afferent axons originating in the hippocampus (PHAL labeled) form multiple contacts with PV-immunoreactive cell bodies (arrowheads) and processes. $D$ and $E$, PHAL-labeled hippocamposeptal axons are forming multiple contacts (arrows) with PV-immunoreactive cells in the medial septum. $F$ and $G$, Retrograde HRP-labeling (black granules labeled with small white arrows) is present in PV-containing cells in the medial septum, which receive multiple contacts (arrows) from PHALlabeled afferents, providing evidence for a direct hippocamposeptal input to PV-positive septohippocampal neurons. $H$, PHAL-labeled boutons $\left(b_{l}, b_{2}\right)$ in contact with the dendrite of a PV-positive, retrogradely labeled (small arrows) cell in the medial septum. $c$, capillary. $I$ and $J$, Highpower light micrographs taken at two different focal planes showing a ChAT-positive, retrogradely labeled (small white arrows) neuron receiving multiple contacts (black arrows) from PHAL-labeled hippocamposeptal axon terminals in the medial septum. Scale bars: $A, 100 \mu \mathrm{m} ; B, 500 \mu \mathrm{m}$; $C, 50 \mu \mathrm{m} ; D-J, 15 \mu \mathrm{m}$.
} 


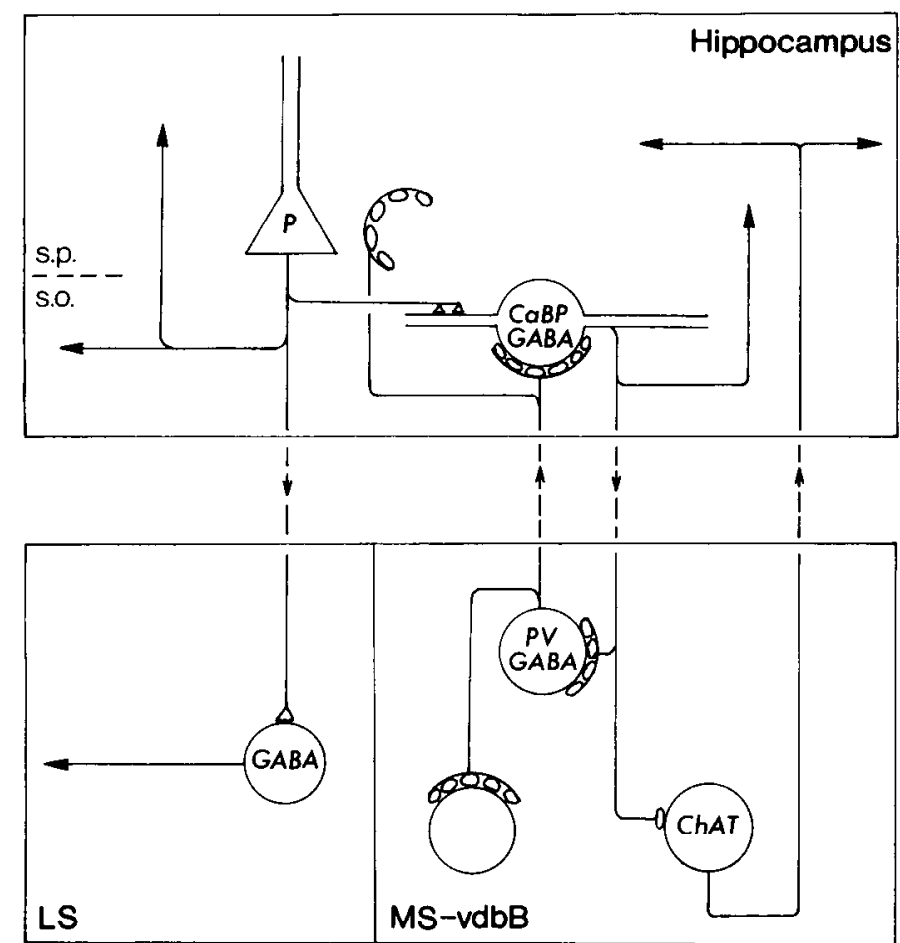

Figure 8. Schematic diagram summarizing the organization of the septo-hippocampo-septal circuit. The cholinergic septohippocampal (ChAT) neurons are the least target selective; they innervate mainly principal cells but also interneurons in the hippocampus (Frotscher and Léránth, 1985). The GABAergic (PV-containing) septohippocampal neurons $(P V, G A B A)$ have local collaterals establishing multiple contacts with both cholinergic and GABAergic septal neurons and, more importantly, they selectively innervate several types of GABAergic interneurons in the hippocampus, including the calbindin $\mathrm{D}_{28 \mathrm{~K}}(\mathrm{CaBP})$-containing cells in stratum oriens of CAl-CA3 (Freund and Antal, 1988). The CaBP-containing nonpyramidal cells in stratum oriens-probably receiving a highly convergent excitatory input from local collaterals of pyramidal cells (which in CAl arborize exclusively in this layer) - are those responsible for the hippocampal GABAergic input to the medial septum, where their major targets are the PV-containing GABAergic neurons, but they also contact the cholinergic cells (Tóth and Freund, 1992; present results). The pyramidal cell projection from the hippocampus terminates exclusively on lateral septal neurons, which apparently do not send a significant projection to the medial septum (Staiger and Nürnberger, 1991; Leranth et al., 1992). Thus, activity in the GABAergic septohippocampal pathway would induce, via disinhibition, an increased and synchronized firing of hippocampal pyramidal neurons, which is likely to result in activation, via local collaterals, of $\mathrm{CaBP}$ containing GABAergic neurons in stratum oriens. These neurons, in turn, would inhibit the GABAergic (PV-containing) septohippocampal neurons, which were the source of disinhibition in the hippocampus. The cholinergic facilitation of hippocampal principal cells is also under a direct, although probably less effective, control of the hippocampal GABAergic feedback.

axons projecting to the lateral septum makes this assumption highly unlikely. Thus, we conclude that most if not all hippocampal neurons projecting directly to the ms-dbB complex are GABAergic.

The GABA immunoreactivity of the postsynaptic targets was equivocal. Previous studies have shown that the level of GABA in GABAergic cells with distant projection (e.g., in Purkinje cells, septohippocampal cells, striatonigral cells) is usually below the threshold of immunocytochemical detection (Panula et al., 1984; Somogyi et al., 1985; Brashear et al., 1986; Onteniente et al., 1986). Therefore, we used PV immunostaining for the identification of GABAergic projection neurons in the ms-dbB complex, as this calcium-binding protein was shown to be selectively present in the GABAergic component of the septohippocampal pathway (Freund, 1989).

\section{Termination of hippocamposeptal axons on identified neurons in the $m s-d b B$ complex}

It has been shown in an earlier light microscopic study (Gaykema et al., 1991) that ChAT-positive neurons are among those contacted by hippocampal axons. However, the present study demonstrates that the majority of the PHAL-labeled axons terminate on PV-immunoreactive neurons in the ms-dbB complex and only a small proportion of the target cells is cholinergic. The PV-immunoreactive septal neurons are known to be GABAergic (Freund, 1989) and to form a cell group with a characteristic distribution, complementary to that of the cholinergic neurons (Kiss et al., 1990a,b). No coexistence between PV and ChAT has so far been found in the ms-dbB complex (Kiss et al., 1990a,b). The PV-containing cell groups in the medial septum are always more medial than the ChAT-positive groups, but the separation is most remarkable in the diagonal band, where ChAT-positive neurons form a ring around a large group of PV-positive cells. This is the area where the preferential innervation of PV-containing neurons is the most striking (see Fig. $7 A-C$ ). In an anterograde study neurons of this region (probably both cholinergic and GABAergic) were shown to innervate the hippocampal formation, most densely the dorsal CAl region and the dorsal dentate gyrus (Nyakas et al., 1987).

\section{Septohippocampal neurons receive monosynaptic feedback from hippocampal nonpyramidal cells}

Earlier studies demonstrated that the septohippocampal cells are found throughout the ms-dbB complex (Meibach and Siegel, 1977; Milner et al., 1983; Amaral and Kurz, 1985; Kiss et al., 1990b). Both the septohippocampal and the hippocamposeptal pathways exhibit some degree of topography (Segal and Landis, 1974; Meibach and Siegel, 1977; Gaykema et al., 1991), and the most medially located septal cells innervate the dorsal hippocampus, whereas more lateral parts of the area send fibers mainly to the ventral hippocampus. Due to this topography we cannot provide a reliable estimate of the relative number of septohippocampal cells innervated by hippocampal axons, but we provided evidence, at the light microscopic level, for the existence of such a connection. In several cases the contacts were multiple, which, even without electron microscopic confirmation, can be taken as evidence for synapses.

\section{Functional implications}

The role of the septohippocampal pathway in the generation and maintenance of hippocampal theta activity is well established (Petsche et al., 1962; Traub et al., 1992). The cholinergic component of this projection has been considered crucial for this function (Vanderwolf, 1971), but in recent studies the GABAergic component was also suggested to be essential (Stewart and Fox, 1989; Smythe et al., 1990). Several lines of indirect evidence suggest that the GABAergic septohippocampal pathway is crucial also for the generation of hippocampal sharp waves, since the septal input is likely to produce a profound disinhibition and rapid synchronization of hippocampal principal cells (Freund and Antal, 1988; Buzsáki, 1989). However, the neuronal circuits and transmitters relaying hippocampal feedback to the medial septal projection neurons were largely 
unknown. Recent studies demonstrated that the lateral septal projection to the medial septum, which was thought to mediate the hippocampal input, is sparse if it exists at all (Staiger and Nürnberger, 1991; Leranth et al., 1992). The major targets of the lateral septum, instead, include hypothalamic areas and the amygdala (Leranth et al., 1992). The hippocampal pyramidal and nonpyramidal projection neurons innervate different parts of the septal region; pyramidal cells project to the lateral septum (Swanson and Cowan, 1979; Joels and Urban, 1984; Stevens and Cotman, 1986; Leranth and Frotscher, 1989; Jakab and Leranth, 1990a), and the medial septal region is innervated by nonpyramidal (calbindin-containing, GABAergic) neurons (Alonso and Köhler, 1982; Tóth and Freund, 1992; present results). Thus, the hippocampo-medial septal pathway is likely to be important since it is the sole route for the hippocampal feedback regulation of the septal region containing septohippocampal neurons.

The identification of the synaptic organization of the septohippocampo-septal circuit (Fig. 8) allows us to propose the following mechanism for reciprocal regulation in this loop. The calbindin-containing nonpyramidal cells in stratum oriens of CAl, which are the major source of GABAergic input to the medial septal neurons, are likely to receive-in addition to inputs from $\mathrm{CA} 3-\mathrm{a}$ highly convergent input from the relatively sparse local collaterals of pyramidal cells known to arborize predominantly in this layer (Lorente de No, 1934). One may speculate that if these nonpyramidal cells had a high firing threshold, then they will be activated only if pyramidal cell discharges reach a high degree of synchrony. It is important to note here that the majority of electrophysiological data available about nonpyramidal cells are likely to derive from the fast-firing neurons, which have a low firing threshold, high spontaneous activity, and contain the calcium-binding protein PV (Kawaguchi and Hama, 1987; Kawaguchi et al., 1987; Lacaille et al., 1987; Lacaille and Williams, 1990; Lacaille, 1991). However, PV-containing cells do not participate in the hippocamposeptal projection (Tóth and Freund, 1992). The only regions in the hippocampus where nonpyramidal cells definitely lacking PV can be reliably recorded from are strata radiatum and lacunosum moleculare, where PV-positive cell bodies are absent (Gulyás et al., 1991). Interneurons in these layers show electrophysiological features strikingly different from those of PV-positive neurons; that is, they are difficult to activate by afferent stimulation and have low if any spontaneous activity and broad action potentials (Kawaguchi and Hama, 1988; Lacaille and Schwartzkroin, 1988). A high proportion of the neurons in these layers contain calbindin (Gulyás et al., 1991), similar to the nonpyramidal cells that project to the medial septum from stratum oriens (Tóth and Freund, 1992). During in vivo extracellular recordings aiming for interneurons, the spontaneously active, fast-firing PV-positive neurons will be picked up in the majority of cases and these PV-containing neurons, which do not participate in the feedback projection to the medial septum, may correspond to the theta cells. Other types of interneurons (including the hippocamposeptal calbindin-containing cells) - which may have occasionally been misclassified as pyramidal cells in extracellular recordings and therefore have not been characterized-are likely to show low firing rates during theta activity, and to discharge synchronously with large pyramidal cell populations during sharp waves. The rapid synchronization shown to occur during sharp waves (Buzsáki ct al., 1983; Buzsáki, 1989) may take place as a result of GABAergic septohippocampal disinhibition (Freund and Antal, 1988). The GABAergic (PVcontaining) septal neurons responsible for the hippocampal disinhibition will then be silenced by the hippocamposeptal GABAergic feedback.

It should be noted, however, that the proposed interactions apply if GABA at all these connections is inhibitory (but see Michelson and Wong, 1991). The circuit interactions proposed above would ensure the rapid termination of the septal generation of hippocampal population synchrony, and provide the essential time lag between hippocampal sharp waves. The low level of activity of CA1-CA3 pyramidal cells observed during theta activity (Buzsáki et al., 1983) may be insufficient for the activation of hippocamposeptal nonpyramidal cells. During this state hippocampal pyramidal cells may still be able to activate lateral septal neurons projecting to hypothalamic areas and the amygdala, without interfering with the septohippocampal pacemaker activity. Thus, we speculate that the direct hippocampal (GABAergic) feedback to medial septal projection neurons is activated mostly during non-theta behaviors and controls septohippocampal disinhibition as a function of hippocampal synchrony.

\section{References}

Alonso A, Köhler C (1982) Evidence for separate projections of hippocampal pyramidal and nonpyramidal neurons to different parts of the septum in the rat brain. Neurosci Lett 31:209-214.

Amaral DG, Kurz J (1985) An analysis of the origins of the cholinergic and noncholinergic septal projection to the hippocampal formation of the rat. J Comp Neurol 240:37-59.

Baimbridge KG, Miller JJ (1982) Immunohistochemical localization of calcium-binding protein in the cerebellum, hippocampal formation and olfactory bulb of the rat. Brain Res 245:223-229.

Baimbridge KG, Miller JJ, Parkes CO (1982) Calcium-binding protein distribution in the rat brain. Brain Res 239:519-525.

Bland BH (1986) The physiology and pharmacology of hippocampal formation theta rhythms. Prog Neurobiol 26:1-54.

Brashear HR, Záborszky L, Heimer L (1986) Distribution of GABAergic and cholinergic neurons in the rat diagonal band. Neuroscience 17:439-451.

Bruce G, Wainer BH, Hersh LB (1985) Immunoaffinity purification of human choline acetyltransferase: comparison of the brain and placental enzymes. J Neurochem 45:611-620.

Buzsáki G (1989) Two-stage model of memory trace formation: a role for "noisy" brain states. Neuroscience 31:551-570.

Buzsáki G, Leung LS, Vanderwolf CH (1983) Cellular bases of hippocampal EEG in the behaving rat. Brain Res Rev 6:139-171.

Cuello AC, Sofroniew MV (1984) The anatomy of the CNS cholinergic neurons. Trends Neurosci 7:74-78.

Freund TF (1989) GABAergic septohippocampal neurons contain parvalbumin. Brain Res 478:375-381.

Freund TF, Antal M (1988) GABA-containing neurons in the septum control inhibitory interneurons in the hippocampus. Nature 336:170173.

Frotscher M, Léránth C (1985) Cholinergic innervation of the rat hippocampus as revealed by choline acetyltransferase immunocytochemistry: a combined light and electron microscopic study. J Comp Neurol 239:237-246.

Gaykema RPA, van der Kuil J, Hersh LB, Luiten PGM (1991) Patterns of direct projections from the hippocampus to the medial septumdiagonal band complex. Anterograde tracing with Phaseolus vulgaris leucoagglutinin combined with immunohistochemistry of choline acetyltransferase. Neuroscience 43:349-369.

Gerfen CR, Sawchencko WM (1984) An anterograde neuroanatomical tracing method that shows the detailed morphology of neurons, their axons and terminals: immunohistochemical localization of an axonally transported plant lectin, Phaseolus vulgaris leucoagglutinin (PHA-L). Brain Res 290:219-238.

Gulyás AI, Görcs T, Freund TF (1990) Innervation of different peptide-containing neurons in the hippocampus by GABAergic septal afferents. Neuroscience 37:31-44. 
Gulyás AI, Tóth K, Danos P, Freund TF (1991) Subpopulations of GABAergic neurons containing parvalbumin, calbindin D28k, and cholecystokinin in the rat hippocampus. J Comp Neurol 312:371378.

Hancock MB (1982) DAB-nickel substrate for differential immunoperoxidase staining of nerve fibers and terminals. J Histochem $\mathrm{Cy}-$ tochem 30:578-579.

Heizmann CW, Celio MR (1987) Immunolocalization of parvalbumin. Methods Enzymol 139:552-570.

Hodgson AJ, Penke B, Erdei A, Chubb IW, Somogyi P (1985) Antisera to gamma-aminobutyric acid. I. Production and characterization using a new model system. J Histochem Cytochem 33:229-239.

Jakab RL, Leranth C (1990a) Catecholaminergic, GABAergic, and hippocamposeptal innervation of GABAergic "somatospiny" neurons in the rat lateral septal area. J Comp Neurol 302:305-321.

Jakab RL, Leranth C (1990b) Somatospiny neurons in the rat lateral septal area are synaptic targets of hippocamposeptal fibers: a combined EM/Golgi and degeneration study. Synapse 6:10-22.

Joels M, Urban JA (1984) Electrophysiological and pharmacological evidence in favor of amino acid neurotransmission in fimbria-fornix fibers innervating the lateral septal complex of the rat. Exp Brain Res $54: 445-462$.

Kawaguchi Y, Hama K (1987) Fast-spiking nonpyramidal cells in the $\mathrm{CA} 3$ region, dentate gyrus and subiculum of rats. Brain Res 425:351355.

Kawaguchi Y, Hama K (1988) Physiological heterogeneity of nonpyramidal cells in hippocampal CAl region. Exp Brain Res 72:494502.

Kawaguchi Y, Katsumaru H, Kosaka T, Heizmann CW, Hama K (1987) Fast-spiking cells in the rat hippocampus (CAl region) contain the calcium-binding protein parvalbumin. Brain Res 416:369-374.

Kiss J, Patel AJ, Freund TF (1990a) Distribution of septohippocampal neurons containing parvalbumin or choline acetyltransferase in the rat brain. J Comp Neurol 298:362-373.

Kiss J, Patel AJ, Baimbridge KG, Freund TF (1990b) Topographical localization of neurons containing parvalbumin and choline acetyltransferase in the medial septum-diagonal band region of the rat. Neuroscience 36:61-72.

Köhler C, Chan-Palay V, Wu J-Y (1984) Septal neurons containing glutamic acid decarboxylase immunoreactivity project to the hippocampal region in the rat brain. Anat Embryol (Berl) 169:41-44.

Lacaille J-C (1991) Postsynaptic potentials mediated by excitatory and inhibitory amino acids in interneurons of stratum pyramidale of the CA1 region of rat hippocampal slices in vitro. J Neurophysiol 66: 1441-1454.

Lacaille J-C, Schwartzkroin PA (1988) Stratum lacunosum-moleculare interneurons of hippocampal CA1 region. I. Intracellular response characteristics, synaptic responses, and morphology. J Neurosci $8: 1400-1410$.

Lacaille J-C, Williams S (1990) Membrane properties of interneurons in stratum oriens-alveus of the CAl region of rat hippocampus in vitro. Neuroscience 36:349-359.

Lacaille J-C, Mueller AL, Kunkel DD, Schwartzkroin PA (1987) Local circuit interactions between oriens/alveus interneurons and CAl pyramidal cells in hippocampal slices: electrophysiology and morphology. J Neurosci 7:1979-1993.

Léránth C, Frotscher $M$ (1989) Organization of the septal region in the rat brain: cholinergic-GABAergic interconnections and termination of hippocamposeptal fibers. J Comp Neurol 289:304-314.

Léránth C, Deller T, Buzsáki G (1992) Intraseptal connections redefined: lack of a lateral septum to medial septum path. Brain Res 583: $1-11$.

Lorente de No R (1934) Studies on the structure of the cerebral cortex. II. Continuation of the study on the Ammonic system. J Psychol Neurol 46:113-175.

Meibach RC, Siegel A (1977) Efferent connections of the hippocampal formation in the rat. Brain Res 124:197-224.

Michelson HB, Wong RKS (1991) Excitatory synaptic responses me- diated by GABA ${ }_{A}$ receptors in the hippocampus. Science 253:1420 1423.

Milner TA, Loy R, Amaral DG (1983) An anatomical study of the development of the septo-hippocampal projection in the rat. Dev Brain Res 8:343-371.

Nyakas C, Luiten PGM, Spencer DG, Traber J (1987) Detailed projection patterns of septal diagonal band efferents to the hippocampus in the rat with emphasis on innervation of $\mathrm{CAl}$ and dentate gyrus. Brain Res Bull 18:533-545.

Onteniente B, Tago H, Kimura H, Maeda T (1986) Distribution of gamma-aminobutyric acid-immunoreactive neurons in the septal region of the rat brain. J Comp Neurol 248:422-430.

Panula P, Revuelta AV, Cheney DL, Wu J-Y, Costa E (1984) An immunocytochemical study on the location of GABAergic neurons in rat septum. J Comp Neurol 229:69-80.

Petsche H, Stumpf C, Gogolak G (1962) The significant of rabbit's septum as a relay station between the midbrain and the hippocampus. The control of hippocampal arousal activity by septum cells. Electroencephalogr Clin Neurophysiol 14:202-211.

Raisman G (1966) The connexions of the septum. Brain 89:317-348.

Scgal M, Landis S (1974) Afferents to the hippocampus of the rat studied with the method of retrograde transport of horseradish peroxidase. Brain Res 78:1-15.

Smythe JW, Lawson VH, Bland BH (1990) The effects of intraseptal infusions of procaine on hippocampal theta-on and -off cells in the urethane anesthetized rat. Soc Neurosci Abstr 16:1097.

Sofroniew MV, Eckenstein F, Thoenen H, Cuello AC (1982) Topography of choline acetyltransferase-containing neurons in the forebrain of the rat. Neurosci Lett 33:7-12.

Somogyi P, Hodgson AJ (1985) Antisera to gamma-aminobutyric acid. III. Demonstration of GABA in Golgi-impregnated neurons and in conventional electron microscopic sections of cat striate cortex. J Histochem Cytochem 33:249-257.

Somogyi P, Soltesz I (1986) Immunogold demonstration of GABA in synaptic terminals of intracellularly recorded, horseradish peroxidase-filled basket cells and clutch cells in the cat's visual cortex. Neuroscience 19:1051-1065.

Somogyi P, Hodgson AJ, Chubb IW, Penke B, Erdei A (1985) Antisera to gamma-aminobutyric acid. II. Immunocytochemical application to the central nervous system. J Histochem Cytochem 33:240-248.

Staiger JM, Nürnberger F (1991) The efferent connections of the lateral septal nucleus in the guinea pig: intrinsic connectivity of the septum and projection to other telencephalic areas. Cell Tissue Res 264:415426.

Stevens DR, Cotman CW (1986) Excitatory amino acid antagonists depress transmission in hippocampal projections to the lateral septum. Brain Res 382:437-440.

Stewart M, Fox SE (1989) Do septal neurons pace the hippocampal theta rhythm? Trends Neurosci 13:163-168.

Swanson LW, Cowan CM (1977) An autoradiographic study of the organization of the efferent connections of the hippocampal formation in the rat. J Comp Neurol 172:49-84.

Swanson LW, Cowan WM (1979) The connections of the septal region in the rat. J Comp Neurol 186:621-656.

Tóth K, Freund TF (1992) Calbindin $D_{28 K}$-containing nonpyramidal cells in the rat hippocampus: their immunoreactivity for GABA and projection to the medial septum. Neuroscience 49:793-805.

Traub RD, Miles R, Buzsáki G (1992) Computer simulation of carbachol-driven rhythmic population oscillations in the CA3 region of the in vitro rat hippocampus. J Physiol (Lond) 451:653-672.

Vanderwolf $\mathrm{CH}$ (1969) Hippocampal electrical activity and voluntary movement in the rat. Electroencephalogr Clin Neurophysiol 26:407418.

Vanderwolf $\mathrm{CH}$ (1971) Limbic-diencephalic mechanism of voluntary movement. J Psychol Rev 78:83-113.

Wainer BH, Levey AI, Mufson EJ, Mesulam MM (1984) Cholinergic system in mammalian brain identified with antibodies against choline acetyltransferase. Neurochem Int 6:163-182. 